\title{
$\mathrm{CVD}$ 法で被覆した $\mathrm{TiC}$ 膜の残留応力と 強度評価に関する X 線的研究 ${ }^{+}$
}

\author{
田中啓介* 伊藤 登史政** \\ 秋 庭 義 明* 石 井 高 博***

\section{X-Ray Study on Residual Stress and Strength of TiC Thin Films Coated by CVD Method}

by

\author{
Keisuke TANAKA ${ }^{*}$, Toshimasa Iтo ${ }^{* *}$, Yoshiaki AkinIwa ${ }^{*}$ and Takahiro IshII ${ }^{* * *}$
}

\begin{abstract}
Thin films of titanium carbide (TiC) were coated on various substrates such as cemented carbide (WC-Co) with different cobalt contents, ferritic and austenitic steels by the chemical vapor deposition (CVD) method. Thin films did not have strong texture. The residual stress in thin films was measured by the $\sin ^{2} \psi$ method of X-ray stress measurement. The residual stress was tensile for WC-Co substrates, while compressive for steel substrates. The residual stress was nearly uniform within the film thickness for the cases of WC-Co substrates, while it had rather steep distribution for the cases of steel substrates. The magnitude of the residual stress increased in proportion to the mismatch of the coefficient of thermal expansion (CTE). The measured stress was more compressive than the prediction by CTE mismatch. Under the uniaxial applied stress, the stress in the thin film was biaxial because of the mismatch of Poisson's ratio, and increased in proportion to the applied strain as predicted from the elasticity relation of coated layers. At high applied strains, the stress in the thin film measured by X-rays did not increase because of cracking. The tensile fracture strength of TiC films on WC-Co substrates was found to be around 750 to $800 \mathrm{MPa}$. This value is about twice the fracture strength of bulk materials.
\end{abstract}

Key words : X-ray stress analysis, Residual stress, Thin films, Titanium carbide, Loading stress, Fracture strength

\section{1 緒}

金属材料の表面にセラミックスを被覆する表面改質技 術は，工具や金型等をはじめとして，耐磨耗性や耐食性， 耐熱性を向上させる目的で機械部品などに広く用いられ ている.この場合，熱膨張係数の違いによる熱応力のほ か, 微視構造に起因する真応力が残留する. 薄膜中の残 留応力は, 被覆膜の破壊やはく離の強度と密接に関係す るため，その実体の把握が重要である. 多結晶薄膜の残 留応力測定法としては，X線法が広く用いられ結晶方位 がランダムな場合ばかりでなく繊維配向をする場合の測 定法も提案されている.

$\mathrm{X}$ 線法では, 残留応力ばかりでなく負荷応力も測定で きるので, X 線法によって膜の弾性特性や破壊強度の検 討も可能であり, 実際に数種の膜に適用されている.

本研究では, 硬質膜として工具などに広く使用されて る炭化チタン $(\mathrm{TiC})$ を, 化学的蒸着法 (CVD 法) によ り種々の熱膨張係数の異なる軟鋼, 機械構造用合金鋼, ステンレス鋼およびコバルト含有量の異なる WC-Co 超 硬合金に被覆し，X線法を用いて膜中の残留応力を測 定した。ついで，外力を負荷したときの膜応力の変化を
$\mathrm{X}$ 線法で測定するとともに, 膜の破壊強度について検討 した.

\section{$2 \cdot 1$ 材料および試験片}

\section{2 実 験 方 法}

基板材料は軟鋼 (JIS SS400)，機械構造用合金鋼 (SNCM439)，ステンレス鋼 (SUS304) およびWC-Co 超 硬合金である。これらの基板の研削仕上げ面に後述の CVD 法により TiC 膜を被覆した。 なお，WC-Co 合金は， コバルト含有量が mass \%で $3,7,10,15,25$ の 5 種類 である. Table I に基板の機械的性質を示す. WC-Coの Co の体積率は, WC の密度 $15.6 \times 10^{3} \mathrm{~kg} / \mathrm{m}^{3}, \mathrm{Co}$ の密 度 $8.9 \times 10^{3} \mathrm{~kg} / \mathrm{m}^{3}$ として mass\%より計算した. ${ }^{8)}$ 基板の ヤング率とポアソン比は 4 点曲げ試験により求めた。 た, $\mathrm{TiC}$ の機械的弾性定数は, 単結晶の弾性定数 ${ }^{9)}\left(C_{11}\right.$ $\left.=514.5 \mathrm{GPa}, C_{12}=105.9 \mathrm{GPa}, C_{44}=178.8 \mathrm{GPa}\right)$ よりラン ダムな方位を持つ多結晶の值を Kröner モデル ${ }^{10)}$ により 算出した。熱膨張係数 (CTE ; Coefficient of thermal expansion) は, WC-Coについては, WC 相を $5.2 \times 10^{-6} /$ $\mathrm{K}, \mathrm{Co}$ 相を $12.5 \times 10^{-6} / \mathrm{K}$ として, Wakashima ${ }^{11)}$ の 式で算出した。その他はカタログ值である。

$\dagger \quad$ 原稿受理 平成 14 年 10 月 10 日 $\quad$ Received Oct. 10, 2002

* 正会員 名古屋大学大学院工学研究科機械工学専攻 ₹464-8603 名古屋市千種区不老町, Dept. of Mech. Eng., Nagoya., Univ., Chikusa-ku, Nagoya, 464-8603

** 学生会員 名古屋大学大学院 ₹464-8603 名古屋市千種区不老町, Graduate Student, Nagoya., Univ., Chikusa-ku, Nagoya, 464-8603

*** いすメ゙自動車㑣藤沢工場 テ252-0806 藤沢市土棚, Fujisawa Plant, Isuzu Motors Limited, Tsuchidana, Fujisawa, 252-0806 
Table I . Thermomechanical properties of materials.

\begin{tabular}{c|c|c|c|c}
\hline Material & $\begin{array}{c}\text { CTE } \\
\left(\times 10^{-6} / \mathrm{K}\right)\end{array}$ & $\begin{array}{c}\text { Young's } \\
\text { modulus } E \\
(\mathrm{GPa})\end{array}$ & $\begin{array}{c}\text { Poisson's } \\
\text { ratio } \\
v\end{array}$ \\
\hline \multicolumn{2}{c|}{ TiC } & 7.6 & 437 & 0.199 \\
\hline \multirow{5}{*}{ WC- } & $3(5.1)$ & 5.4 & 601 & 0.205 \\
mass\%Co & $7(11.7)$ & 5.8 & 569 & 0.222 \\
& $10(16.3)$ & 6.0 & 534 & 0.212 \\
& $15(23.6)$ & 6.4 & 480 & 0.226 \\
& $25(36.9)$ & 7.2 & 404 & 0.236 \\
\hline SS400 & 11 & 207 & 0.282 \\
\hline \multicolumn{2}{c|}{ SNCM439 } & 11 & 204 & 0.282 \\
\hline \multicolumn{2}{c|}{ SUS304 } & 16 & 196 & 0.294 \\
\hline \multicolumn{2}{c}{}
\end{tabular}

基板試験片の形状は，幅 $10 \mathrm{~mm}$ ，長さ $55 \mathrm{~mm}$ の板材で ある。 また厚さは WC-Co 基板の mass\%Co が 7, 10 抢よ び 15 材の及板厚が $1.4 \mathrm{~mm}$ で，他は $3 \mathrm{~mm}$ である.

$\mathrm{CVD}$ は, 水素, メタン, 四塩化チタン, アルゴンの混 合気体中で $1273 \mathrm{~K} て ゙$ 行った。被覆した TiC 膜の厚さは $6 \mu \mathrm{m}$ である。

\section{$2 \cdot 2 \mathrm{X}$ 線応力測定}

$\mathrm{X}$ 線応力測定は，X線回折用ディフラクトメータ（島 津製作所 XD-D1，マックサイエンス MXP18）に平行ビ 一ムのスリットを装着し，並傾法で行った． TiC は立方 晶で, 格子定数はJCPDS カード No. 6-0614によると a $=0.43285 \mathrm{~nm}$ である. X 線測定条件を Table IIにまとめ る。特性 X線には $\mathrm{Fe}-\mathrm{K} \alpha$ 線を使用し, TiC331 回折を測定 した。 なお X線の管電流と管電圧は, XD-D1 では $40 \mathrm{kV}$, $30 \mathrm{~mA}$ で, MXP18 は 30kV, 200mA である.また, 表中 に示す TiC331 回折に打けるXX線的弾性定数は単結晶の弾 性定数 ${ }^{9)}$ より Kröner モデル ${ }^{10)}$ を用いて求めた。

後述のように, 本実験の薄膜の配向性は小さく, ほぼ ランダムは方位を有していた。このためX線応力測定は 通常の $\sin ^{2} \psi$ 法で行った。測定したプロフィルは平滑化 の後, バックグラウンド除去, LPA 因子の補正, $\mathrm{K} \alpha_{2}$ 線 を除去した補正プロフィルに対して, 回折角を半価幅中 点法によって決定した．X線入射は， $\psi$ 一定法で，傾斜 角 $\psi$ は $\sin ^{2} \psi$ 間隔が 0 から 0.6 まで 0.1 刻みの 7 点を基 本として設定した。 なお TiC331 回折に対する X 線の侵 入深さは 1.4 から $3.2 \mu \mathrm{m}$ である.

\section{$2 \cdot 3$ 負荷応力下での $\mathrm{X}$ 線応力測定}

被覆材に 4 点曲げ荷重を負荷した。このときのピンの

Table II . X-ray conditions for stress measurement.

\begin{tabular}{l|c}
\hline Method & Parallel beam method \\
\hline Characteristic Xray & Fe- $\mathrm{K} \alpha$ \\
\hline Diffraction plane $\quad$ TiC $(331)$ \\
Diffraction angle (deg) & 154.6 \\
Filter & $\mathrm{Mn}$ \\
Irradiated area $\quad\left(\mathrm{mm}^{2}\right)$ & 25 \\
Scanning speed $\quad(\mathrm{deg} / \mathrm{min})$ & 1 \\
Preset time $\quad(\mathrm{sec})$ & 2 \\
\hline X-ray Young's modulus (GPa) & 433 \\
X-ray Poisson's ratio & 0.202 \\
Stress constant (MPa/deg) & -709 \\
\hline \multicolumn{2}{l}{}
\end{tabular}

内スパンは $20 \mathrm{~mm}$ で, 外スパンが $44 \mathrm{~mm}$ である. 試験片 の TiC 膜面を引張り面とし，その面にひずみゲージを添 付し，負荷ひずみを段階的に増加させた，各ひずみでの 軸方向の応力およびそれに垂直な横方向の応力を X 線測 定した.

\section{$2 \cdot 4$ 膜面の電子顕微鏡 $(\mathrm{SEM})$ 観察}

$\mathrm{TiC}$ 膜面を荷重負荷前, および荷重負荷後に電界放射 型走査型電子顕微鏡 (SEM：JEOL JSM-6330F) によっ てき裂の有無を観察した。観察時の加速電圧は 5 $10 \mathrm{kV}$ で超音波洗浄後コーティングなしで行った。一方, WC-Co 基板試験片および SS400 基板試験片ではひずみ 負荷中に適宜レプリカを採取し，そのレプリカに $\mathrm{Au} の$ コーティングを行い, 加速電圧 $5 \mathrm{kV} て ゙$ 観察した.

\section{$2 \cdot 5$ 残留応力分布の測定}

膜内部の残留応力分布を電解研磨（過塩素酸と酢酸の 体積比 $1: 10$ の混合液) で逐次表面層を除去し, 応力測 定を繰り返すことにより求めた．また膜厚の除去による 応力緩和を補正 ${ }^{12)}$ を行ったが, 実際の補正值は $1 \mathrm{MPa}$ 以 下で小さい.

\section{3 実験結果および考察}

$3 \cdot 1$ 表面の残留応力

本試験で得られた $\mathrm{TiC}$ の薄膜の集合組織はほとんど認 められなかった. Fig. 1に例として WC-25mass\%Co 基 板上の薄膜について補正後の回折プロフィルの積分強度

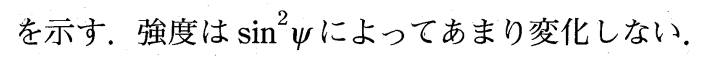

無負荷状態で得られた $2 \theta-\sin ^{2} \psi$ 線図の例を Fig. 2 に 示す.いずれの材料に扔いても回折角と $\sin ^{2} \psi$ の関係は 直線近似が可能であり，顕著な非線形性は認められない。 四中の直線は回帰直線である。また, 基板が SS 400 , SNCM439 およびSUS304 の場合の直線は右上がりで圧 縮残留応力であるが，WC-Co 基板で Co の mass\%が低 い場合は右下がりで引張り残留応力となる。 また, これ らの直線はほほ 1 点で交わっているが，このときの $\sin ^{2} \psi$ の值は残留応力が等 2 軸であるとすると次式から求めら れる。

$$
\sin ^{2} \psi=\frac{2 v}{1+v}=0.319
$$

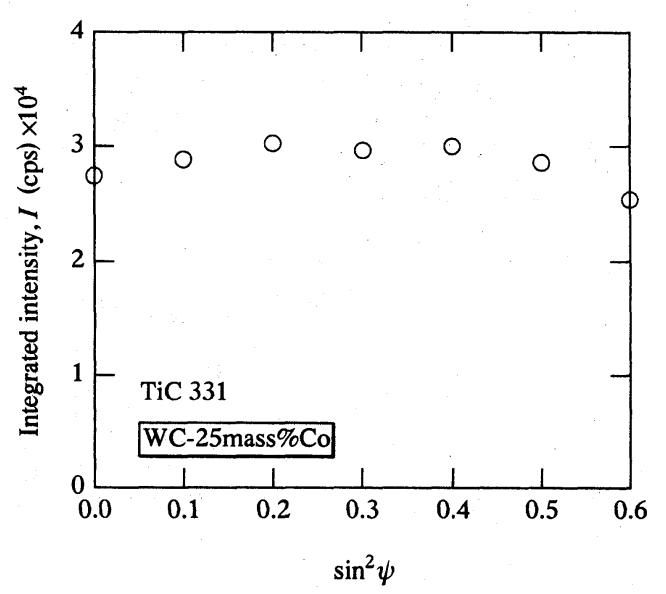

Fig. 1. Integrated intensity of $\mathrm{TiC}$ film deposited on WC-25mass\%Co. 


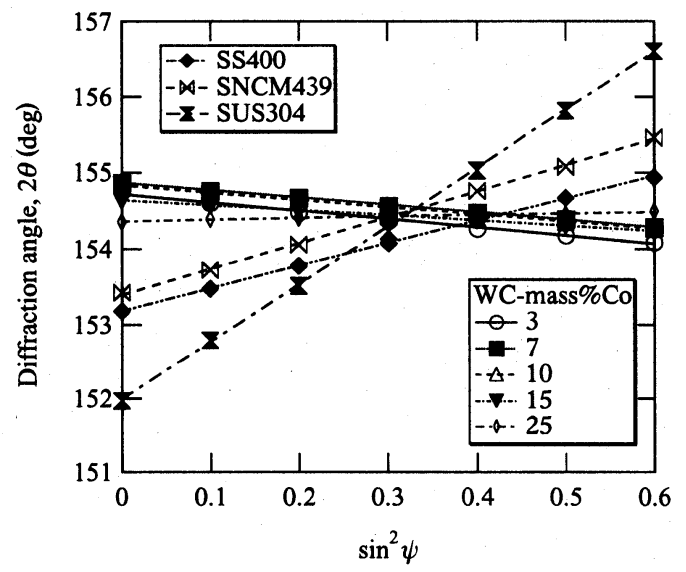

Fig. 2. $2 \mathrm{q}-\sin 2 \mathrm{y}$ diagram for $\mathrm{TiC}$ film on various substrates.

ここで $v は \mathrm{TiC}$ のポアソン比であり, Table I 中の值を 用いた。この值は図中の交点とほぼ一致する。

Fig. 3 には各材料について測定された残留応力を，熱 膨張係数の差 $\Delta \alpha$ に対して示す．ここで, $\Delta \alpha$ は膜の CTE から基板の CTE を引いた値である。 また， CTEのミス マッチによって生ずる熱残留応力は応力緩和が生じない とすると次式で求められる.

$$
\sigma_{\text {them }}=E \Delta \alpha \Delta T /(1-v)
$$

ここで, $E$ は膜の機械的ヤング率とポアソン比である. また, $\Delta T$ は成膜温度と室温の差である。これに, Table I の值を代入して求めた応力と $\Delta \alpha$ の関係を図中の直線 で示す．困より，測定された残留応力值は式 (2)による 予測より圧縮側となっており，その差は $\Delta \alpha か ゙$ 負に大き くなるほど大きい，実測値が計算値より少し圧縮側とな るのは，真応力の寄与によるものと考えられる.

\section{$3 \cdot 2$ 膜中の応力の負荷ひずみによる変化}

被覆材に Fig. 4 に示すような, 被覆材の基板に 4 点曲 げにより 1 軸応力を加え，そのときの膜応力を X 線測定 した。このとき引張り面に添付したひずみゲージにより 負荷ひずみ $\varepsilon_{\mathrm{A}}$ を測定した．まず，Fig. 4 に示すように被 覆材の基板に 1 軸応力を加えた場合の薄膜中の応力状態 について検討する，基板の面内ひずみを $\varepsilon_{11}^{\prime} ， \varepsilon_{22}^{\prime} と し ，$ 膜

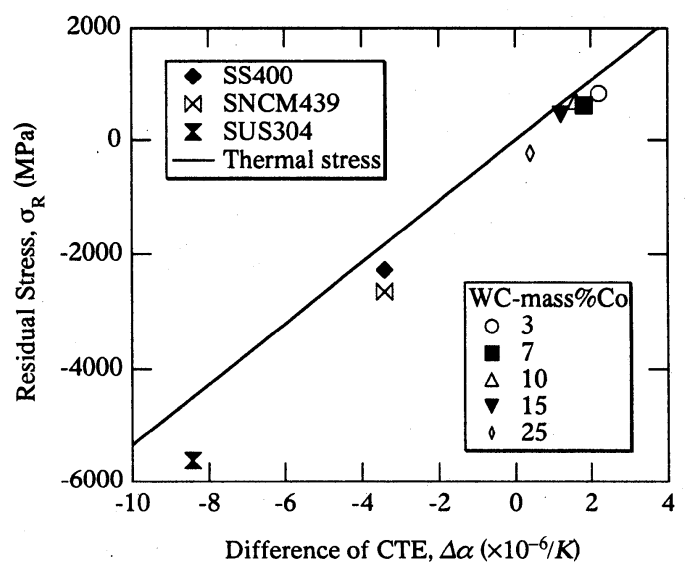

Fig. 3. Variation of residual stress of TiC films with CTE mismach.

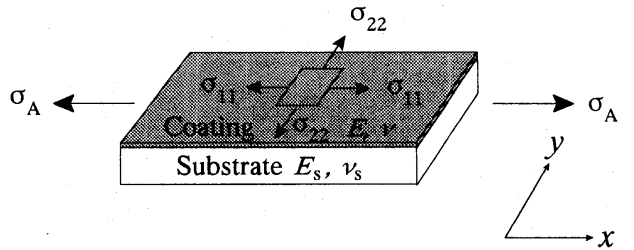

Fig. 4. Thin films coated on the substrate under uniaxial tension.

内のそれらを $\varepsilon_{11}, \varepsilon_{22}$ とする. 1 軸応力 $\sigma_{\mathrm{A}}$ を $\mathrm{x}$ 軸方向に 加えた場合, 膜と基板は接着されているため, ひずみが 等しいので次式が成立する.

$$
\begin{aligned}
& \varepsilon_{11}=\varepsilon_{11}^{\prime}=\varepsilon_{\mathrm{A}} \\
& \varepsilon_{22}=\varepsilon_{22}^{\prime}=-v_{\mathrm{s}} \varepsilon_{\mathrm{A}}
\end{aligned}
$$

ここで， $\varepsilon_{\mathrm{A}}$ はひずみゲージで測定されるひずみであり， $v_{\mathrm{S}}$ は基板のポアソン比である. 膜中の面内応力 $\sigma_{11}, \sigma_{22}$ は，平面応力であるので次式が成立する。

$$
\begin{gathered}
\sigma_{11}=\frac{E}{1-v^{2}}\left(\varepsilon_{11}+v \varepsilon_{22}\right)=\frac{1-v v_{\mathrm{S}}}{1-v^{2}} E \varepsilon_{\mathrm{A}} \\
\sigma_{22}=\frac{E}{1-v^{2}}\left(\varepsilon_{22}+v \varepsilon_{11}\right)=\frac{v-v_{\mathrm{S}}}{1-v^{2}} E \varepsilon_{\mathrm{A}}
\end{gathered}
$$

このように基板に 1 軸の応力を加えても，ポアソン比の ミスマッチにより膜は 2 軸応力となることが予想される. 上式は負荷ひずみによる応力の変化量であり，実際には 残留応力がこの值に重畳する.

弾性範囲のひずみを加えた場合の $2 \theta-\sin ^{2} \psi$ 線図の例 を Fig. 5 に示す.ここで，(a) が負荷方向 ( $\mathrm{x}$ 軸方向) で（b）がそれに垂直な横方向（y 軸方向）である. 負荷 方向に関して，負荷ひずみを加えた場合も直線近似が可 能であり，かつひずみとともに直線勾配は小さくなる. ここで，直線はほぼ一点を中心に集まるが，このときの $\sin ^{2} \psi$ は, Fig. 2 の場合と異なり, 0.2 から 0.25 である. ここで式 (5)，(6)を用いると次式となる.

$$
\sin ^{2} \psi=\frac{v}{1+v} \frac{\sigma_{11}+\sigma_{22}}{\sigma_{11}}=\frac{v}{1+v} \frac{1+v-v_{\mathrm{s}}-v v_{\mathrm{S}}}{1-v v_{\mathrm{s}}}
$$

この式を用いると WC-25mass\%Co 材では, $\sin ^{2} \psi$ が 0.160 となる. よって Fig. 5 (a)中での直線群の交点が, Fig. 2 中の交点より小さくなることが説明できるが，上の式で は残留応力を無視しているので絶対值は一致しない，一 方, Fig. 5 (b)の横方向は, 傾きがあまり変わらず負荷ひ ずみとともに高回折角側に平行移動する。

Fig. 6 (a), (b)に 4 点曲げ試験の結果得られた X 線測 定応力と負荷ひずみの関係を示す。また図中には式 (5), (6)から得られる予測直線を同時に示す，ただし SS400 材 では基板はひずみ負荷によって塑性変形すると考元, 基 板のポアソン比が 0.50 としたときの直線も示す。 また予 測式 (5), (6) は負荷ひずみによる応力の変化量であり, 図中ではこれに残留応力を加えた。まず，Fig. 6 (a)の $\mathrm{WC}-25 \mathrm{mass} \% \mathrm{Co}$ 基板では応力 は負荷ひずみ $\varepsilon_{\mathrm{A}}$ とともに 変化しその変化挙動は予測直線とほぼ等しくなる。さら に負荷ひずみを増加させるとある值以上では引張り応力 の増加は見られなくなる.

負荷試験と平行して行ったレプリカ観察により得られ 


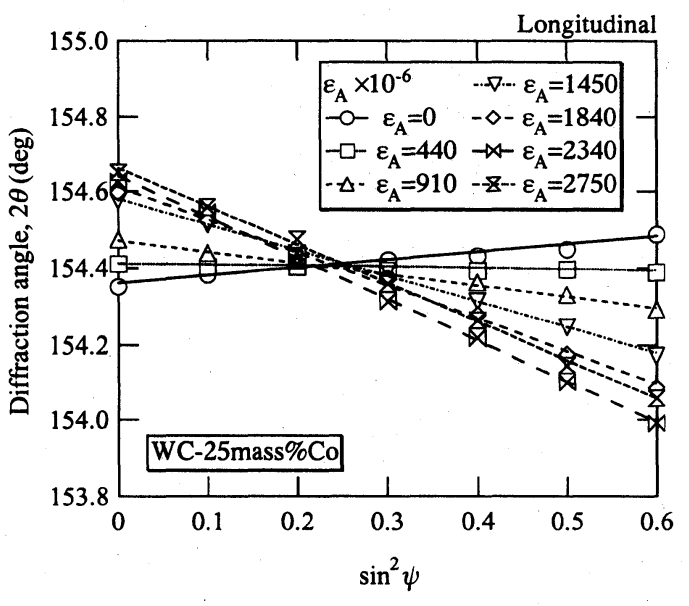

(a) Longitudinal

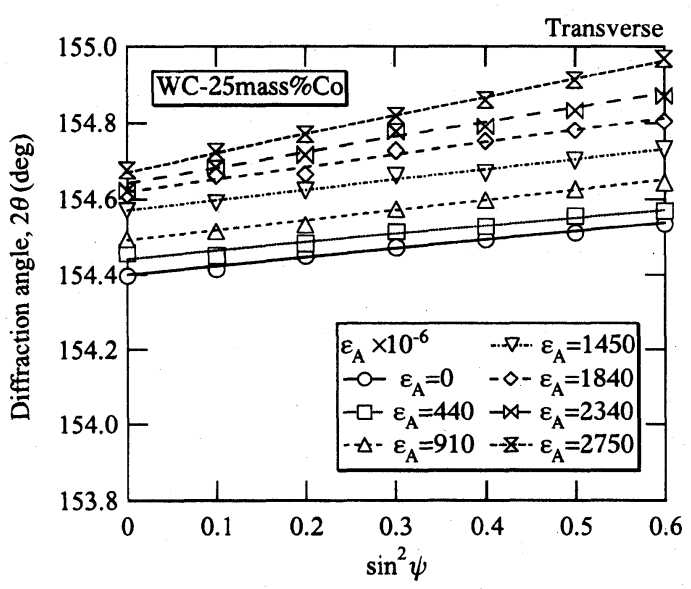

(b) Transverse

Fig. 5. $2 \theta-\sin ^{2} \psi$ diagram for TiC film with applied strain.

た，き裂が最初に確認されたひずみを矢印で示す。この ように，き裂は応力が増加しなくなる以前に発生してい た。さらにひずみを負荷するとそれらのき裂の全長は長 くなり，数も増加した。 このように，き裂が形成された ために，膜中の応力は増加しなくなったと考えられる.

Fig. 6 (b)の SS400 基板の場合では同様な傾向が得ら れる．ここで $\sigma_{22}$ に着目すると，(a)と同様に負荷ひずみ が小さい領域では基板のポアソン比を 0.282 としたとき の直線に従う。さらに負荷ひずみを増加させると, 基板 のポアソン比が 0.5 としたときの直線に従った. なお，図 中に示すようにレプリカ観察によるき裂の発生が最初に 確認されたときの応力は圧縮であった.

基板が異なった場合に対しても負荷試験を行ったが， 同様な傾向が認められた，実験で得られた，負荷試験に おける膜中の最大応力の X 線測定結果を Table III にまと める。成膜処理過程において既にき裂が生じていた WC3 および 7 mass\%Co 材では初期残留応力を記した。ここ で，最大応力を膜の破壊応力と見なすと，WC-Co 基板で はばらつきはあるものの破壊応力はほぼ一定である。ま た，鉄鋼基板の場合の破壊応力は WC-Co 基板よりも小 さな引張であるが，これは後述のように残留応力が分布

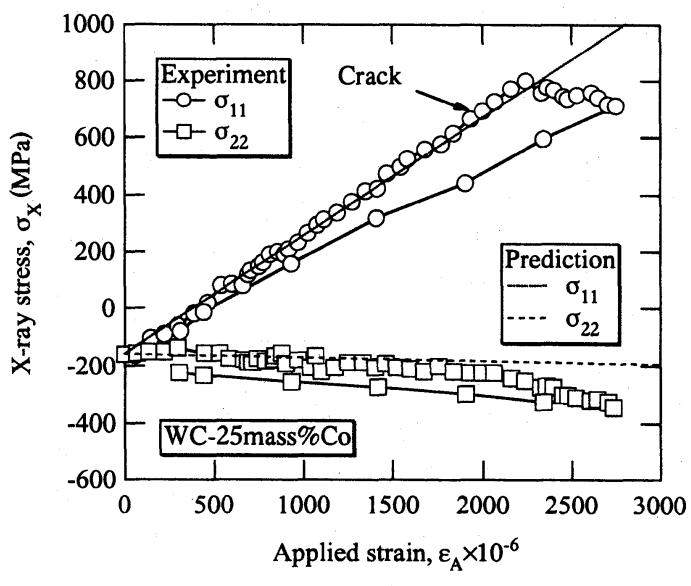

(a) WC-25mass $\% \mathrm{Co}$

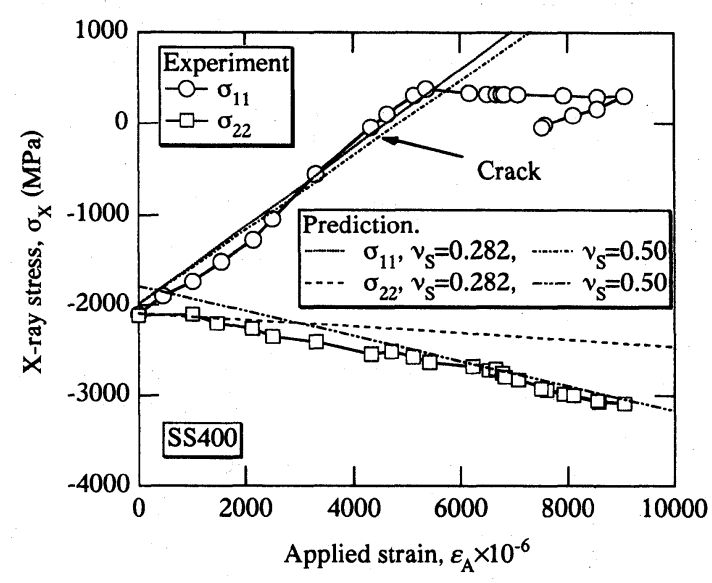

(b) SS400

Fig. 6. Change of X-ray stress with applied strain in TiC film.

Table III. Maximum tensile stress measured in TiC film.

\begin{tabular}{c|c|c}
\hline \multicolumn{2}{c|}{ Substrate } & Maximum stress (MPa) \\
\hline \multirow{4}{*}{ WC-Co } & 3 & $(822)$ \\
\cline { 2 - 3 } (Cowt\%) & 7 & $(618)$ \\
\cline { 2 - 3 } & 10 & 783 \\
\cline { 2 - 3 } & 15 & 754 \\
\hline \multicolumn{2}{c}{ SS400 } & 803 \\
\hline \multicolumn{2}{c|}{ SNCM439 } & 379 \\
\hline \multicolumn{2}{c}{ SUS304 } & 159 \\
\hline
\end{tabular}

( ) Initial residual stress

していることに起因しており，WC-Co 基板の 750 $800 \mathrm{MPa}$ が TiC 膜の破壊強度と考えられる。この WC-Co 基板の場合の值は $\mathrm{Ueki}^{13)} ら に よ る \mathrm{HIP}$ で製造したバル クの $\mathrm{TiC}$ の曲げ強さ $420 \mathrm{MPa}$ よりも大きく, 薄膜の方が 強度が倍程度高くなる。

Fig. 7 には Fig. 6 で行った実験をもとに，負荷ひずみ が WC-Co 基板では $200 \sim 300 \times 10^{-6}$ まで, 鉄鋼基板で は約 $2000 \times 10^{-6}$ までの場合に求められた，負荷ひずみ に対する X 線測定した長手方向の応力の変化率と負荷応 力の変化率との比を, CTE ミスマッチに対して示す.こ 


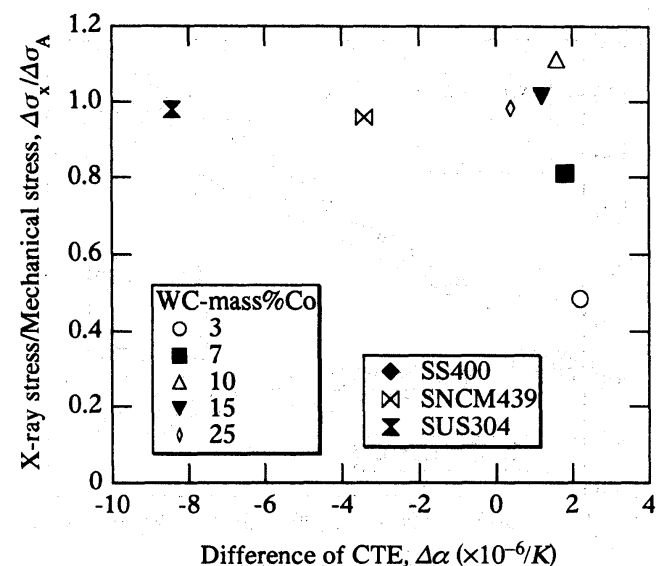

Fig. 7. Change of $\Delta \sigma_{\mathrm{X}} / \Delta \sigma_{\mathrm{A}}$ with difference of CTE.

こで, 負荷応力の変化率の計算には Table I 中の弾性特 性を用いて式 (5)から算出した。成膜後き裂が認められ ない場合にはだいたい 1 に近いが，成膜時にすでにき裂 が存在する WC-3 および 7mass\%Co 材の場合には，それ ぞれ 0.5 および 0.8 程度と他と比較して小さくなる。こ れは, 膜中のき裂のため, 式 (5)で求められる応力が伝

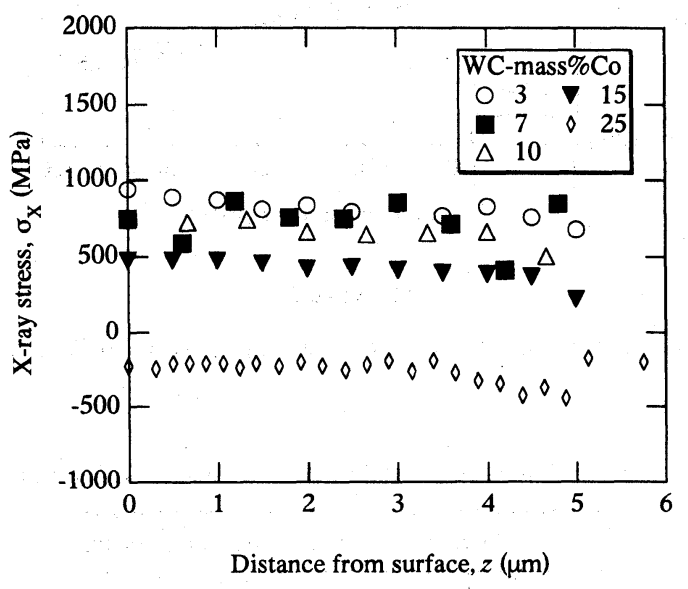

(a) WC-Co substrates

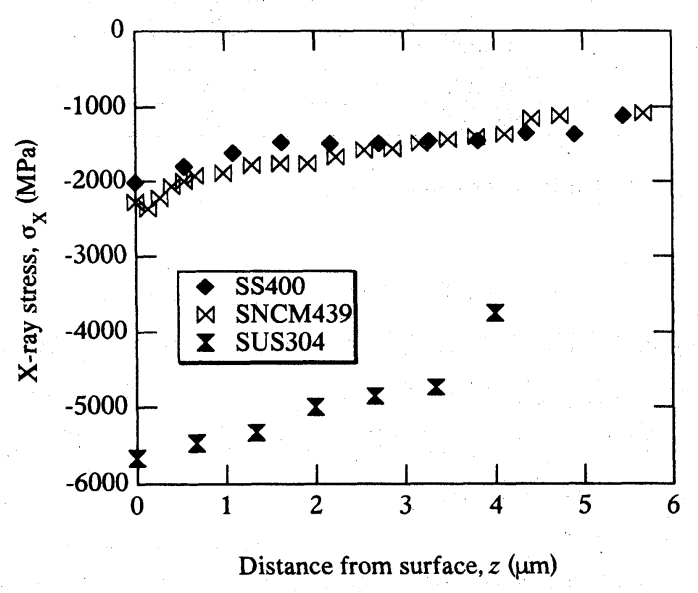

(b) Steel substrates

Fig. 8. Distribution of residual stress in TiC film deposited on various substrates.
わっていないことに対応する。このようにX線的に弾性 範囲での X 線応力と負荷応力の関係を求めることから逆 に膜のき裂の状態が評価できる.

\section{$3 \cdot 3$ 膜中の残留応力の分布}

Fig. 8 には膜を逐次研磨することによって得られた残 留応力と膜表面から深さ方向への距離の関係を示す．(a) の WC-Co 基板では膜中の応力はほぼ一定であった。 そ れに対して (b) の鉄鋼基板では圧縮残留応力の大きさが 表層から徐々に減少していく，它して初期残留応力のほ ぼ等しいSS400, SNCM439 基板では界面付近での残留 応力は約-1000MPa の圧縮残留応力となった. SUS304 基板ではそれらよりも大きな圧縮応力であった。このよ うに界面に近づくほど残留応力が緩和している理由は成 膜温度が $1273 \mathrm{~K}$ という高温のため基板の変態や基板の塑 性変形によるものであると考えられる.

この結果をもとに前項の負荷試験の X 線測定応力の挙 動を検討する. Fig. 8 (a)の WC-Co 基板の場合では膜中 の応力が一定であることから, 膜表面からの測定応力が 膜中の応力を代表している。このためX線法によって測 定された值 $750 \sim 800 \mathrm{MPa}$ が $\mathrm{TiC}$ 膜の破壊強度とみなさ れる。一方 Fig. 8 (b)の鉄鋼基板の場合，X線応力が圧 縮であるのにき裂が認められたが，これは膜と基板の界 面付近では膜応力がすでに引張に転じており，そこから き裂が生じたと考元られる。また，鉄鋼基板で膜の破壊 強度が小さくなるのは, 膜中の残留応力分布に起因する。 そのため鉄鋼基板の $\mathrm{TiC}$ 膜の破壞強度の測定のためには， 残留応力分布も含めた検討が必要である.

\section{3・4 SEM による表面観察}

Fig. 9 に TiC 膜面の SEM 観察結果を示す. (a) は WC-3 mass\%Co 材の成膜段階での状態，(b) は WC-25mass\%Co 材の負荷前，(c) は WC-25mass\%Co 材の負荷後，(d) は SS400 材の負荷試験後のものである。ここでは紙面横方 向が試験片長手方向で負荷応力方向と一致している．(a) の WC-3mass\%Co 材でのみ成膜段階でき裂が観察された。 このように成膜段階でのき裂には方向性がない。これは 膜に対して残留応力が等方的に作用しているからである.

一方 (b) では成膜後にき裂が観察されていないが，(c) のように負荷方向に垂直にき裂が認められた． 4 点曲げ による主応力垂直方向にき裂が生じたと考えられる。一 方，(d)に示すように初期残留応力が大きな圧縮である 鉄鋼基板でも，負荷後は主応力垂直方向にき裂が生じた. また，レプリカ観察では垂直方向以外のき裂は確認され ず，初期残留応力が約 $-2000 \mathrm{MPa}$ の大きな压縮でも成膜 段階ではき裂が生じていない。.また，レプリカ観察によ ると負荷ひずみの増加とともにき裂も長くなり，数も増 加した。

\section{4 結言}

種々の超硬合金および鉄鋼に, CVD 法により TiC 薄 膜を形成した。残留応力打よび負荷応力を $\sin ^{2} \psi$ 法によ りX線測定した。得られた結果をまとめるとつぎのよう になる。

（1）膜中の残留応力は，CTE ミスマッチより予測さ 


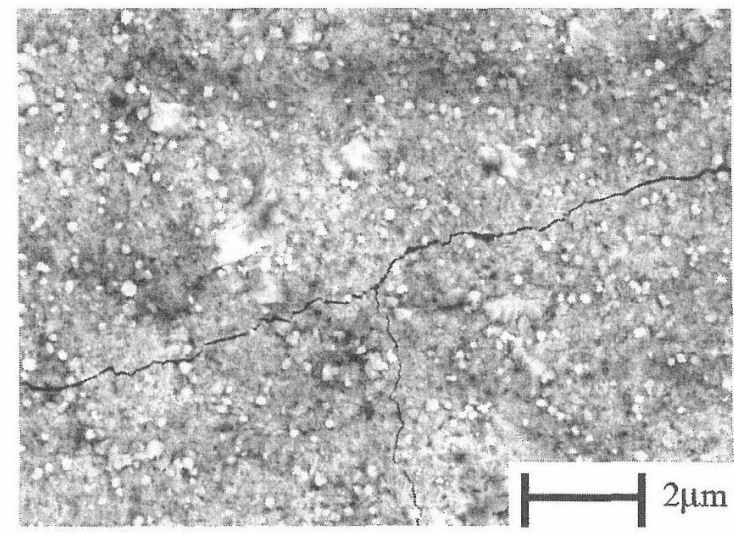

(a) WC-3mass $\% \mathrm{Co}$, Before loading

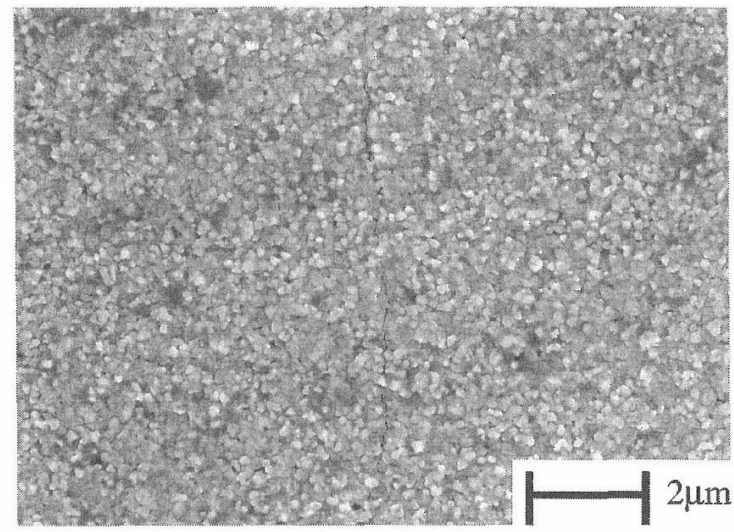

(c) WC-25mass $\%$ Co, After unloading

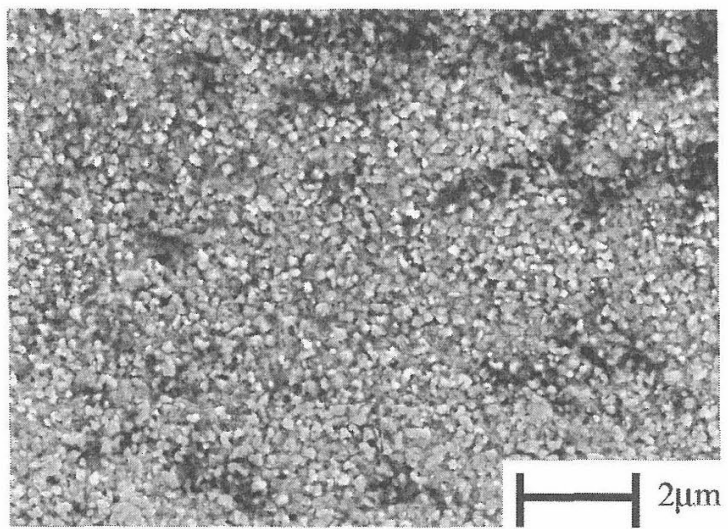

(b) WC-25mass \%Co, Before loading

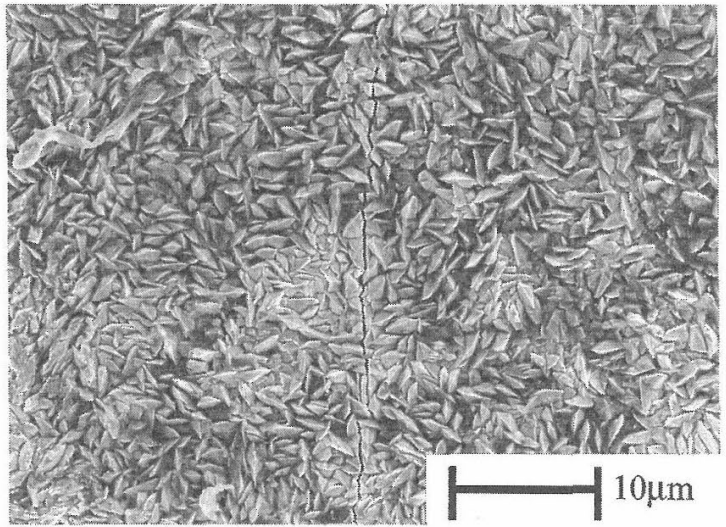

(d) SS400, After unloading

Fig. 9. Scanning electron micrographs of TiC films.

れる熱残留応力と同様に，ミスマッチに比例して烈化す るが，絶対値はやや圧縮側で市った。また，引張り残留 応力が測定された WC-3 抢よび $7 \mathrm{mass} \% \mathrm{Co}$ 基板材では成 膜段階でのき裂が認められた。

（2）膜中の残留応力分布はWC-Co 基板ではほぼ一定 であった。只れに対し鉄鋼基板では界面に接近するにつ れ圧縮応力が減少した。これは成膜時における基板の変 態や降伏によるものと考学られる。

（3）４点曲げ試験に扣ける膜中の応力は，負荷ひずぬ が小さい範围でほぼ線形的に増大寸る。き裂のない試験 片では，負荷ひずみに対する增加の挙動は，薄膜材の変 形挙動による予測と一致する。

（4）負荷ひずみが大きくなると，膜中の X 線応力は増 加しなくなるがこれは朕中に亀裂が生じたためである。

（5） X 線法で測定した WC-Co 基板上の TiC 膜の引張 破壞応力は，打上学 $750 \mathrm{MPa} \sim 800 \mathrm{MPa}$ で崩った。この 破壞応」の值はバルクの値の 2 倍程度である。

\section{参 考 文 献}

1）日本材料学会編，“X線応力測定”，p. 54 (1981) 養賢堂.

2) K. Tanaka, K. Ishihara and Y. Akiniwa, Adv. X-Ray Analysis, 39, 251 (1997)

3) K. Tanaka, Y. Akiniwa, T. Ito and K. Inoue, JSME Inter. J., A42, 224 (1998).

4) T. Hanabusa, Mater. Sci. Res. Inter., 5, 63 (1999).

5) 田中啓介, 雇 青萍, 御屌照明, 秋庭義明, 日本機械学 会論文集，A-62，2734 (1996)。

6) K. Tanaka, T. Ito, Y. Akiniwa, H. Kimachi and Y. Miki, Mater. Sci. Res. Intern., 6, 231 (2000).

7) K. Tanaka, T. Ito, Y. Akiniwa, T. Ishii and Y. Miki, Mater. Sci. Forum, 404-407, 703 (2002).

8）世中啓介, 松并元康, 世中 拓, 材料, 42, 96 (1993).

9) R. Chang and L. J. Graham, J. Appl. Phys., 37, 3778 (1966).

10) E. Kröner, Z. Phys., 151, 504 (1958).

11) K. Wakashima, M. Otsuka and S. Umekawa, J. Comp. Mater., 8, 391 (1974).

12）田中敬介，峰 典明，鈴木賢治，川瀬良一，材料，40， 96 (1991).

13) M. Ueki and H. Endo, ISIJ Int., 32, 943 (1992). 